\section{Fatigue and Efficiency in the Iron and Steel Industry.}

I N Report No. 5 of the Industrial Fatigue Research Board Dr. H. M. Vernon describes the results of a series of investigations carried out at most of the chief iron and steel centres in the United Kingdom. He points out that there are tremendous variations in the mechanical efficiency of the plant employed in various works and in the efficiency with which human labour is utilised. In most districts the blast furnaces are charged by hand, though four to eight times more men are required than for mechanical charging, and the work is of a much heavier character. In the most efficiently run open-hearth steel furnaces two to three times more charges of steel are worked per week than in the least efficient, whilst the efficiency of rolling mills varies in similar proportion.

The steel-melters, when engaged in mending their furnaces, which they usually do immediately after the molten steel has been drawn off and whilst they are still white-hot, have to undertake one of the most arduous forms of labour known in any industry. Much might be done to lighten this labour, for at some works the average time required for mending is seven times longer than at others; also, owing to the fact that all the furnaces are started at about the same time, they tend to require mending at the same time, so the men frequently cannot relieve one another. This could be remedied by arranging that mending was more evenly spread over the week. Many of the steel furnaces are still charged by hand, in spite of the tremendous labour and delay involved.

The effect of fatigue on health and longevity was studied by Dr. Vernon (in conjunction with Mr. E. A. Rusher) by tabulating the sickness and mortality data of 24,000 iron and steel workers for a six-year period. These data, which had accrued under the National Health Insurance Act, showed that there is a definite relationship between the amount of sickness experienced by the workers and the nature of their occupation. Steel-melters headed the list, and showed 23 per cent. more sickness than the average and 26 per cent. greater mortality. The puddlers of wrought-iron showed a 20 per cent. excess of sickness, the whole of this excess being due to respiratory diseases and rheumatism. Presumably this was because the puddlers usually work alternate 20-minute periods of very hot and heavy work followed bv light work or complete rest, during which they tend to catch chills. Other workers at hot and heavy work likewise showed an excess of sickness, whilst workers at ordinary temperatures, such as cranemen and general labourers, showed 9 per cent. less sickness than the average.

\section{University and Educational Intelligence.}

Mr. James W. Low, assistant in the natural history department of University College, Dundee, has been appointed lecturer in zoclogy at Birkbeck College, London.

The Manchester Education Committee has appointed Prof. B. M. Jones to be principal of the Manchester College of Technology in succession to Principal Garnett. Prof. Jones, who was educated at Oxford, was for some time professor of chemistry at the Government College, Lahore, and more recently professor of chemistry at, and director of, the Edward Davies Chemical Laboratories, Aberystwyth.

Science for February 25 announces that Prof. J. R. Angell was elected president of Yale University at a meeting of the University Corporation on February 20 ; the new president will take up his duties at the close of the university vear. Prof. Angell is a graduate of the University of Michigan, and has been professor of psychology, dean, and acting president of Chicago University. He has also shown ability as an adminis. trator and a leader of education while acting as chairman of the National Research Council and as president of the Carnegie Corporation.

A LIST of the students and teachers from the Dominions overseas and from foreign countries at present in our universities, which supplements that issued in December last and referred to in Nature of December 30 , p. $5^{85}$, has been issued by the Universities Bureau of the British Empire. Although the information is not yet quite complete, an interesting summary has been compiled showing the numbers which are contributed by each of the continents. Africa sends 1046; America and the West Indies, 676; Asia, 1228, of whom 974 are from India, Burma, and Ceylon; Europe, 703; and Australasia, 282. The grand total to date is thus 3935 , of whom about twothirds are from our overseas Dominions.

The Carnegie Corporation of New York has entered into an agreement with the Leland Stanford University of California by which it will give large financial support to a research institute which the University is about to establish for the intensive study of the problems of the production, distribution, and consumption of food. The need for such research was first brought to the attention of the Corporation by $\mathrm{Mr}$. Herbert $\mathrm{C}$. Hoover, and it is proposed that the institute shall bear his name. The selection of the University as its home is partly due to the fact that Mr. Hoover has deposited there the documentary material he has collected relative to the economic side of the war. The work of research, for which the laboratories of the University will be made available, is to begin on July 1.

The Pioneer Mail for February I8 publishes extracts from the presidential address delivered by Lt.-Col. J. W. D. Megaw to the Medical Research Section of the Indian Science Congress. Col. Megaw states that of late persistent rumours have been circulated that the Government of India is not prepared to undertake the full responsibility for the School of Tropical Medicine and Hygiene of Calcutta and Bombay because all its funds are wanted for the establishment of a new Imperial Institute of Medical Research in Delhi. The school was established largely through the initiative of Sir Leonard Rogers with funds subscribed by the public and grants from the Government. Col. Megaw alludes to the valuable work done by the school, and pleads earnestly for its proper support, suggesting that the programmes of medical research in India should be considered by an authoritative committee of experts.

La Nature for March ig gives some extracts from the statistics of attendance at the University of Paris which have been published in L'Université de Paris. Before the outbreak of war the total number of students in the University was 17,308 ; in the succeeding four years there was naturally a big drop, while in 1918 the numbers had risen again to 11,026 , a figure only about a thousand short of the rg io total. In 1919 there was a big influx of students, much as our own universities experienced, and the total rose to 17,761 ; but surprising figures are given for 1920 , from which it appears that only II,2 14 students were in attendance. The distribution of the totals among Frenchmen and others and among men and women also reveal some strange facts. The figures for the men classed as "étrangers" for I920 show a decrease of about one-fifth of the 1913 total, while for women the decrease for the same period is fully two-thirds. The numbers of Frenchmen attending the Universitv have decreased almost by one-half, while the numbers 
of French women students increased by a similar amount. In another table are shown the numbers of students who attended at the faculties of law, medicine, science, arts, and pharmacy for the various years. From these it appears that the faculty of science is alone in claiming an increase on previous years in the numbers of its students, the figures given being 1175 for 1913 , I 999 for 1919 , and 1558 for 1920 .

THE seventh annual report of the Carnegie United Kingdom Trust gives an account of the activities of the Trust during I920. The high cost of materials and labour made it impossible to erect buildings even when the plans had been already approved; indeed, the trustees felt that they ought not to divert labour and material from the urgent needs of housing. Meanwhile, a special reserve of $414,765 l$. has accumu. lated to meet the claims of those who had been promised building grants. Unfortunately, this sum will be quite inadequate to carry out the work proposed unless there should be a heavy fall in the cost of building. For the quinquennium $192 \mathrm{I}-25$ the trustees allot provisionally $250,000 l$. for library grants of all kinds. They had already promised, in the event of statutory powers being granted to county authorities enabling them to maintain county library schemes, to provide the capital outlay for every county in Great Britain which had not yet adopted a pioneer scheme under the auspices of the trustees. These powers were granted by the Public Libraries Act of 19 ig, and the trustees will now fulfil their promise. The Trust has continued its support to the Central Library for Students, and now proposes to help the rural libraries to lend to genuine students who mav live far from any public library the more expensive books necessary for their studies. Among other grants made during rg20 we notice 4000 . to the London School of Economics in connection with the very Tarse extension of its premises, roool. towards the initial expenses of a library to provide merchant seamen with books while at sea, and $\mathrm{rcool}$. to the National Institute of Pswchologr. An important function of this institute will be to advise manufacturers as to factory conditions and economy of labour.

During the summer term at King's College. Strand, Mr. J. H. Jeans will give four lectures on "Cosmogony and Stellar Evolution" on Mav 3, Io, I7, and 24 at 5 p.m. The first lecture will deal with observation evidence, the second with the effect of rotation on gaseous masses, the third with the effect of rotation on liauid or semi-liquid masses, and the last with the effect of tidal encounters. Mr. Jeans's intention is to give an account of recent observational and theoretical research in non-technical form so as to be intelligible not only to astronomers and mathematicians, but also to geologists and all acquainted with simple scientific terminologv. On Mav $\mathrm{O}, \mathrm{II}$, and $\mathrm{I} 3$, at $5 \mathrm{p.m}$, in King's College, Prof. N. Bohr will lecture on "The Quantum Theory of Radiation and the Constitution of the Atom." At University Collese a course of three lectures on "Oceanography, with Special Reference to the British Isles," will be delivered by Prof. H. N. Dirkson on June $\mathrm{I} 7$ and 24 and Julv $\mathrm{I}$ at $5.30 \mathrm{p.m}$. It is also announced that the course of lectures entitled "A Historical Review of Meteorological Theorv," by Sir Napier Shaw, has been postponed; it will commence on April 29, and one lecture will be given each week until June io. All the lectures mentioned are intended for advanced students of the Universitv and others interested in such subjects; admission is in all cases free and. with the exception of Sir Napier Shaw's lectures, without ticket. Tickets for Sir Napier Shaw's lectures can be obtained from the Meteorological Office, South Kensington, S.VV.7.

\section{Calendar of Scientific Pioneers.}

April 1, 1863. Jacob Steiner died.-Referred to as "the greatest geometrical genius since the time of Apollonius," Steiner treated geometry synthetically. A chair of geometry was created especially for him at Berlin.

April 1, 1900. St. George Jackson Mivart died.Originally a barrister, Mivart took up medical and biological studies, and became well known by his writings. For short periods he held professorships at the Roman Catholic University in London, and also at Louvain.

April 1, 1901. François Marie Raoult died.-From I870 until his death, Raoult was professor of chemistry at Grenoble. His work on solutions, begun in 1878 , had a profound influence on the development of both chemistry and physics. He was awarded the Davy medal in 1892 .

April 2, 1872. Samuel Finlay Breese Morse died.An artist by profession, Morse first transmitted messages by electricity in 1835 , exhibited his apparatus in New York in 1837 , and in I844 connected Baltimore and Washington by telegraph. His well-known alphabet was invented during a voyage in 1832 .

April 3, 1879. Heinrich Wilhelm Dove died.-A professor of natural philosophy in the University of Berlin, Dove added, much to the science of meteoro$\log y$.

April 3, 1900. Joseph Louis Francois Bertrand died.-Secretary of the Paris Academy of Sciences and a professor in the Ecole Polytechnique, Bertrand for fifty years was a prominent member of the French mathematical world

April 4, 1617. John Napier died.-A man of many interests, Napier first published his invention of logarithms in 1614 when sixty-four years of age. His work has been described as one which in the history of British science can be placed as second only to Newton's " Principia.'

April 4, 1827. Ernst Florens Friedrich Chladni died.--One of the founders of the science of acoustics, Chladni was of Hungarian extraction, and for some time held the chair of jurisprudence at Leipzig.

April 4, 1870. Heinrich Gustav Magnus died.-A physicist of Berlin, Magnus was an inspiring teacher, and was known for his researches on heat and other subjects.

April 4, 1919. Sir William Crookes died--Trained as a chemist by Hofmann, Crookes at an early age attained high rank as an investigator. His discovery and study of thallium, invention of the radiometer, study of electric discharges in high vacua, experiments on the rare earths and on glasses, and investigation of psychic phenomena were but a few of the subjects with which he dealt. His work, moreover, in many cases was a starting-point of important modern developments. Knighted in 1807 , he received the Order of Merit in I9Io. and during I9I3-14 served as president of the Royal Society.

April 6, 1829. Niels Henrick Abel died.--Still under twenty-seven years of age when he died, Abel held a place among the greatest mathematicians of his day. His main work related to the theory of elliptical functions.

April 6, 1913. Adolf C. H. Slaby died.--The inventor with Count Årco of a system of wireless telegraphy, Slabv made his first successful experiments in I 897 in the Roval Gardens on the Havel.

E. C. S. NO. 2683 , VOL. IO7] 